\title{
Efek Quercetin terhadap Kadar Adipocyte-Fatty Acid Binding Protein
}

\section{The Effect of Quercetin on Adipocyte-Fatty Acid Binding Protein Level}

\author{
Sudiarto ${ }^{1}$, Setyawati Soeharto $K^{2}$, Shinta Febrina $N^{3}$ \\ ${ }^{1}$ Laboratorium IImu Faal Fakultas Kedokteran Universitas Brawijaya Malang \\ ${ }^{2}$ Laboratorium Farmakologi Fakultas Kedokteran Universitas Brawijaya Malang \\ ${ }^{3}$ Pendidikan Dokter Fakultas Kedokteran Universitas Brawijaya Malang
}

\begin{abstract}
ABSTRAK
Diet tinggi lemak, meningkatkan resiko aterosklerosis akibat stress oksidatif LDL yang di tunjukkan dengan peningkatan petanda inflamasi Adipocyte Fatty Acid Binding Protein ( A-FABP ). Quercetin, senyawa flavonoid mempunyai potensi antioksidan. Penelitian dilakukan untuk membuktikan efek pemberian quercetin terhadap penurunan serum A-FABP. Desain post test only control group dilakukan dengan hewan coba tikus wistar jantan yang di bagi dalam 2 kelompok control dengan diet normal dan $1 \%$ methylcellulose group, diet tinggi lemak dengan $1 \%$ methylcellulose, dan tiga kelompok perlakuan dengan diet tinggi lemak dan pemberian quercetin dosis $2 \mathrm{mg} / \mathrm{kgBB}, 10 \mathrm{mg} / \mathrm{kgBB}$, quercetin $50 \mathrm{mg} / \mathrm{kgBB}$. Berbeda dengan hipotesis uji pearson menunjukkan hubungan korelasi positif peningkatan dosis quercetin dengan AFBP serum concentrations ( $p<0.05, r=0,97$ ).
\end{abstract}

Kata Kunci : Adipocyte-Fatty Acid Binding Protein, diet tinggi lemak, quercetin

\section{ABSTRACT}

High Fat Diet (HFD) increase the risk of atherosclerosis due to oxydative stress of LDL indicated by elevation of Adypocyte Fatty Acid Binding Protein an inflamatory marker. Quercetin, a flavanoid compund, has been assumed as a potential antioxidant. This study aimed to investigate the impact between quercetin dose and decreasing of A-FABP serum concentration. A post test only control group using male wistar rats divided into two control groups which are 1) normal diet with 1\% methylcellulose group, 2) high fat diet with 1\% methylcellulose, and three treatment groups which are high fat diet groups with $2 \mathrm{mg} / \mathrm{kgBB}, 10 \mathrm{mg} / \mathrm{kgBB}$, quercetin $50 \mathrm{mg} / \mathrm{kgBB}$. Pearson correlation test showed the positive correlation betwen quercetin dose and AFBP serum concentrations $(p<0.05, r=0,97)$.

Keywords: Adipocyte -Fatty Acid Binding Protein, High Fat Diet, quercetin

Jurnal Kedokteran Brawijaya, Vol. 26, No. 1, Februari 2010; Korespondensi: Sudiarto. Laboratorium IImu Faal Fakultas Kedokteran Universitas Brawijaya Malang, Jl. Veteran Malang Tel.(0341)569117Email:ve_ra2004@yahoo.com 


\section{PENDAHULUAN}

Salah satu patofisiologi utama aterosklerosis adalah pembentukan foam cells di sub endotel arteri. Foam cells berasal dari monosit atau makrofag yang memfagosit LDL teroksidasi. Komplek foam cells akan membentuk inti lemak, dan bersama lapisan pembungkusnya yang berupa jaringan fibrotik dan otot polos ini akan membentuk plak aterosklerosis $(1,2)$.

Dislipidemia, terutama kadar LDL yang tinggi merupakan faktor resiko utama aterosklerosis. Namun beberapa penelitian memperlihatkan, justru LDL yang teroksidasi memiliki peranan yang lebih besar $(3,4)$. LDL teroksidasi mampu menembus pembungkus plak dan inti lemak, selanjutnya mengakibatkan disintegrasi endotel dan fibrous cap (lapisan pembungkus plak) yang timbul karena aktivasi inflamasi lewat pelepasan sitokin oleh makrofag $(5,6)$.

Stres oksidatif merupakan penyebab utama oksidasi LDL. Beberapa penelitian menunjukkan bahwa oksidasi LDL dapat memodulasi munculnya Adipocyte-Fatty Acid Binding Protein $(A-F A B P)$ yaitu suatu protein intrasel pengikat asam lemak yang diekspresikan di dalam adiposit (sel lemak) dan berfungsi sebagai regulator fungsi biologis adiposit (7-10). A-FABP ditemukan dalam sirkulasi (terutama serum), dan berasosiasi kuat dengan kejadian sindrom metabolik. Sehingga $A-F A B P$ dapat digunakan sebagai penanda sindrom metabolik (11-14).

Quercetin merupakan flavanoid yang banyak terdapat di alam. Quercetin, sebagai anti oksidan dipercaya dapat melindungi tubuh dari beberapa penyakit degeneratif, dengan mencegah peroksidasi lemak $(15,16)$. Quercetin memperlihatkan kemampuan mencegah oksidasi LDL dengan cara menangkap radikal bebas dan menghelat ion logam transisi (17). Melihat potensi quercetin tersebut, dilakukan penelitian untuk menilai hubungan antara efek quercetin sebagai anti-oksidan terhadap kadar $A-F A B P$ sebagai penanda sindrom metabolik pada serum tikus putih jantan (Rattus norvegicus) galur Wistar dengan diet tinggi lemak (DTL) $(11-13,18)$.

\section{METODE}

Jenis penelitian ini adalah true experimental laboratorium, dengan rancangan eksperimen sederhana (post test control group design). Pengkondisian tikus wistar jantan dengan berat badan awal sekitar \pm 150 gram ditempatkan pada suhu $25 \pm 1^{\circ} \mathrm{C}$ dengan siklus cahaya 12 jam (08.00-20.00).

Pengelompokan objek eksperimen dilakukan dengan randomisasi komplek, dengan 25 ekor tikus Wistar jantan dibagi 5 grup dengan masing-masing terdiri dari 5 ekor tikus. Selanjutnya perlakuan untuk masing-masing grup dapat dilihat pada Tabel 1.

Tabel 1. Perlakuan pada masing-masing grup

\begin{tabular}{lccc}
\hline Grup & $\begin{array}{c}\text { Perlakuan pada 12 } \\
\text { minggu I ( Fase I ) }\end{array}$ & $\rightarrow$ & $\begin{array}{l}\text { Perlakuan pada 8 minggu } \\
\text { terakhir ( Fase II ) }\end{array}$ \\
\hline K1 & DN & $\rightarrow$ & DN \\
K2 & DTL & $\rightarrow$ & DN \\
PQ1 & DTL & $\rightarrow$ & DN + quercetin $2 \mathrm{mg} / \mathrm{kg} \mathrm{BB}$ \\
PQ2 & DTL & $\rightarrow$ & DN + quercetin $10 \mathrm{mg} / \mathrm{kg} \mathrm{BB}$ \\
PQ 3 & DTL & $\rightarrow$ & DN + quercetin $50 \mathrm{mg} / \mathrm{kg} \mathrm{BB}$ \\
\hline
\end{tabular}

Keterangan : DN: diet normal, DTL : diet tinggi lemak. Pemberian quercetin dihentikan 2 hari sebelum akhir penelitian.
Efek Quercetin terhadap Kadar... 25

Diet tinggi lemak (DTL) pada fase 1 (12 minggu pertama) tersusun dari Confeed PAR-S 200gr, terigu $100 \mathrm{gr}$, kolestrol $8 \mathrm{gr}$, asam kolat $0,8 \mathrm{gr}$, minyak babi $20 \mathrm{ml}$, dan air 71,2 $\mathrm{ml}$. Dilanjutkan fase II selama 8 minggu dengan diet normal, dengan tujuan menghilangkan efek DTL. Pemberian quercetin secara oral memakai sonde selama fase II dan dihentikan 2 hari sebelum penelitian berakhir untuk mempelajari efek jangka panjangnya.

Pada akhir penelitian, tikus dipuasakan semalam. Darah diambil dari vena ekor. Serum diperoleh dari sentrifugasi darah dengan kecepatan 2000 rpm selama 15 menit. Kadar $A-F A B P$ diukur dari serum tikus menggunakan metode ELISA indirect

\section{HASIL}

Didapatkan perbedaan yang signifikan berat badan pada minggu ke 12 antara grup DN dengan DTL. Rata-rata berat badan grup DTL lebih besar dibandingkan grup DN secara bermakna $(p<0,05)($ Tabel 2$)$.

Tabel 2. Perubahan berat badan masing-masing grup

\begin{tabular}{llll}
\hline $\begin{array}{l}\text { Grup } \\
\text { Perlakuan }\end{array}$ & BB awal & $\begin{array}{l}\text { BB akhir minggu } \\
\text { ke 12 }\end{array}$ & $\begin{array}{l}\text { BB akhir minggu } \\
\text { ke 20 }\end{array}$ \\
\hline K1 & $154,26 \pm 6,07$ & $185,40 \pm 8,20$ & $195,07 \pm 9,23$ \\
K2 & $152,58 \pm 11,75$ & $269,60 \pm 7,23$ & $211,42 \pm 23,76$ \\
PQ1 & $149,53 \pm 7,89$ & $259,80 \pm 9,73$ & $203,8 \pm 17,99$ \\
PQ 2 & $156,92 \pm 16,38$ & $279,80 \pm 11,82$ & $217,57 \pm 17,64$ \\
PQ 3 & $145,46 \pm 8,87$ & $267,20 \pm 15,58$ & $207,95 \pm 17,44 r$ \\
\hline
\end{tabular}

Keterangan : BB : berat badan.

Analisis kadar $A-F A B P$ dengan uji t tidak berpasangan pada akhir fase II memperlihatkan kadar A-FABP pada grup DTL lebih tinggi secara signifikan dibandingkan grup DN $(p<0,05)$. Uji Pearson memperlihatkan korelasi positif yang signifikan antara dosis quercetin dengan kadar $A-F A B P$, dan memiliki kekuatan korelasi yang sangat kuat ( $p<0.05, r$ $=0,97)$.

Tabel 3.Rerata kadar A-FABP

\begin{tabular}{cc}
\hline Grup & $\begin{array}{c}\text { Rata-rata kadar A-FABP } \pm \\
\text { simpangan baku }\end{array}$ \\
\hline K1 & $113,1 \pm 34,54$ \\
K2 & $201,0 \pm 40,43$ \\
PQ1 & $314,3 \pm 109,43$ \\
PQ2 & $386,4 \pm 90,81$ \\
PQ3 & $409,8 \pm 48,98$ \\
\hline
\end{tabular}

\section{PEMBAHASAN}

Pemberian DTL pada studi ini dilakukan agar tikus mengalamipeningkatan berat badan dan meningkatkan resiko aterosklerosis.

Dalam penelitian ini parameter yang digunakan hanya berdasarkan pada berat badan saja. 
Idealnya perlu dilakukan pengukuran kadar trigliserida, $\mathrm{HDL}$, LDL, dan kolesterol pada tikus dengan DTL $(4,5)$.

Diet tinggi lemak selama 12 minggu menyebabkan perubahan berat badan tikus secara signifikan. Lemak selain memiliki nilai kalori lebih tinggi dibanding karbohidrat dan protein, juga lebih sukar dikatabolisme menjadi energi dibandingkan karbohidrat. Apabila tidak terdapat permintaan energi berlebih, lemak cenderung disimpan dalam sel adiposit $(1,5)$. Rata-rata kadar $A-F A B P$ antara grup dengan pemberian DTL pada fase I lebih tinggi secara bermakna dibanding grup dengan DN. Hal ini sesuai dengan teori bahwa peningkatkan berat badan tikus, diharapkan akan diikuti peningkatan penanda sindrom metabolik dan inflamasi, yaitu $A-F A B P(10-14)$.

Temuan yang menarik didapatkan pada efek pemberian quercetin terhadap kadar A-FABP. Diharapkan quercetin sebagai antioksidan dapat menurunkan kadar $A-F A B P$

\section{DAFTAR PUSTAKA}

1. Ross R. The Pathogenesis of Atherosclerosis: $A$ Perspective for the 1990s. Nature. 1993; 362: 801.

2. Faxon DP, Fuster V, Libby $\mathrm{P}$, et al. Atherosclerotic Vascular Disease Conference: Writing Group III: Pathophysiology. Circulation. 2004; 109(21): 2617.

3. Tsimikas S, Bergmark C, Beyer RW, et al. Temporal Increases in Plasma Markers of Oxidized Low-density Lipoprotein Strongly Reflect the Presence of Acute Coronary Syndromes. Journal of the American College Cardiology. 2003; 41: 360.

4. Inoue $T$, Uchida $T$, Kamishirado $H$, Takayangi $K$, Hayashi T, and Morooka S. Clinical Significance of Antibody Against Oxidized Low Density Lipoprotein in Patients with Atherosclerotic Coronary Artery Disease. Journal of American College Cardiology. 2001; 37: 775.

5. Bui MN, Sack MN, Moutsatsos G, et al. Auto-antibody Titers to Oxidized LDL in Patients with Coronary Atherosclerosis. American Heart Journal. 1996; 131: 663.

6. Indriyanti RS. Peran Asam Lemak Bebas, Stres Oksidatif \& Keadaan Inflamasi Terhadap Kejadian Resistensi Insulin. Forum Diagnosticum. 2006: 6: 3439.

7. Mulyohadi A, Djanggan S, Ketut M, et al. Effect of Seaweeds Caulerpa Racemosa in Atherogenic Diets of Rats (Rattus norvegicus Strain Wistar). Proyek Penelitian Grup Atherosklerosis Biomedik Universitas Brawijaya. Fakultas Kedokteran Universitas Brawijaya, Malang. 2002.

8. Peeters W, Kleijn DP, Vink A, et al. Adipocyte Fatty Acid Binding Protein in Atherosclerotic Plaques is Associated with Local Vulnerability and is Predictive for the Occurence of Adverse Cardiovascular Events. European Heart Journal. 2011; 32(4): 1758-1768.

9. Layne $\mathrm{MD}$, Patel A, Chen $\mathrm{YH}$, et al. Role of Macrophage-expressed Adipocyte Fatty Acid Binding Protein in the Development of Accelerated Atherosclerosis in Hypercholesterolemic Mice. The sebagai penanda sindrom metabolik. Korelasi positif yang signifikan dengan kekuatan korelasi yang sangat kuat antara dosis quercetin dan kadar $A-F A B P$.

Salah satu penjelasan dari fenomena ini adalah dugaan quercetin juga merupakan pro-oksidan. Sebuah penelitian menemukan bahwa quercetin selain sebagai anti-oksidan ternyata dapat berperan sebagai pro-oksidan (19). Perubahan fungsi quercetin ini mengakibatkan quercetin yang seharusnya memiliki fungsi sebagai zat penghambat inflamasi justru bekerja sebagai zat penginduksi inflamasi . Quercetin bisa berperan sebagai pro-oksidan pada beberapa kejadian terutama pada pemakaian terlalu sering dan atau dalam dosis besar (20).Pada penelitian ini dilakuakn pemberian quercetin selama 8 minggu. Studi lanjut perlu dilakukan untuk mengkaji hubungan jangka waktu pemberian quercetin dengan efek pro-oksidannya.

Journal of the Federation of American Societies for Experimental Biology. 2001; 15(14): 2733-2735.

10. Makowski L and Hotamisligil GS. The Role of Fatty Acid Binding Proteins in Metabolic Syndrome and Atherosclerosis. Current Opinion Lipidology. 2005; 16(5): 543-548

11. Perrella MA, Pellacani A, Layne MD, et al. Absence of Adipocyte Fatty Acid Binding Protein Prevents the Development of Accelerated Atherosclerosis in Hypercholesterolemic Mice. The Journal of the Federation of American Societies for Experimental Biology. 2001; 15(10): 1774-1776.

12. Furuhashi M, Tuncman G, Gorgun CZ, et al. Treatment of Diabetes and Atherosclerosis by Inhibiting FattyAcid Binding Protein aP2. Nature Review Drugs Recovery. 2007; 447: 959-965.

13. Furuhashi M and Hotamisligil GS. Fatty Acid Binding Proteins: Role in Metabolic Diseases and Potential as Drug Targets. Nature Review Drugs Recovery. 2008; 7: 489-503.

14. Xu A, Wang Y, Xu J, et al. Adipocyte Fatty Acid Binding Protein is a Plasma Biomarker Closely Associated with the Obesity and Metabolic Syndrome. Clinical Chemistry. 2006; 52(3): 405-413.

15. Kawai $\mathrm{Y}$, Nishikawa $\mathrm{T}$, Shiba $\mathrm{Y}$, Saito $\mathrm{S}$, et al. Macrophage as a Target of Quercetin Glucuronides in Human Atherosclerotic Arteries. The Journal of Biological Chemistry. 2008; 283(14): 9424-9434.

16. Enkhmaa B, Shiwaku K, Katsube T, et al. Mulberry Leaves and Their Major Flavonol Quercetin Attenuate Atherosclerotic Lesion Development in LDL ReceptorDefficient Mice. Journal of Nutrition. 2005; 135(4): 729-734.

17. Reiterer G, Toborek M, and Hennig B. Quercetin Protects Against Linoleic Acid-induced Porcine Endothelial Cell Dysfunction. The Journal of Nutrition. 2004; 1(34): 771-775

18. Hayek T, Fuhrman B, Vaya J, et al. Reduced Progession 
of Atherosclerosis in Apoliporotein E-defficient Mice Following Consumption of Red Wine, or its Plyphenol Quercetin or Catechin, is Associated with the Reduced Susceptibility of LDL to Oxydation and Aggregation. Ateriosclerosis, Thrombosis and Vascular Biology Journal. 1997; 17(11): 2744-2752.
19. Afanas'ev IB, Dorozhko AJ, Brodski AV, Kostyuk AV, and Potapovitch Al. Chelating and Free Radical Scavenging Mechanisms of Inhibitory Action of Rutin and Quercetin in Lipid Peroxidation. Biochemical Pharmacology. 1989; 38(11): 1763-1769.

20. Clark LJ. Interstitial Cystitis Quercetin. National Center for Biotechnology Information. 2010; 32: 155. 